\title{
Energy and Exergy Performance Calculation of Solar Photovoltaic/ Thermal Hybrid System under the Baghdad Environment
}

\author{
Dheya Ghanim Mutasher Mohammed Fowzi Mohammed Zaid Salman Obaid \\ Mechanical Engineering Department, University of Technology, Baghdad, Iraq
}

\begin{abstract}
dr.dheya@gmail.com Mohammed2007msc@yahoo.com zaid.sal87@gmail.com
\end{abstract}

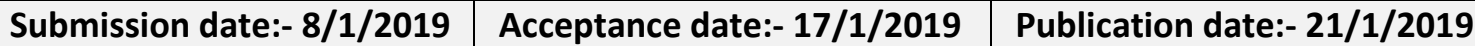

\begin{abstract}
A combined system with photovoltaic panel modules, which extracts heat from water or air and produces thermal and electrical energy which is called a solar photovoltaic or solar thermal photovoltaic thermal (PV/T) system. A way to enhance the electrical efficiency of the PV module is by diminishing the temperature at which the module is working, i.e. by extracting thermal energy. The design of the solar Photovoltaic/Thermal provides certain advantages. When the temperature is increased $1^{\circ} \mathrm{C}$, the photoelectric efficiency decrease by $0.5 \%$. This work is principally aimed to clarify the effectiveness by means of the exergy generated in a PV/T hybrid water module, a photovoltaic thermal module, generating thermal and electrical energy. Were determined the energy, exergy and the efficiency of the power conversion for a certain amount of days in function of the solar intensity, the temperature of the module and environmental temperature. During the hours 9:00 am to 3:00 pm, the efficiencies of exergy and power conversion varies according to the following values, between $2.16-12.27 \%$ for the exergy efficiency and between $5.2-11.2 \%$ for the power conversion efficiency as well as, the energy efficiency varies between $6.89-14.9 \%$. The temperature of the photovoltaic module has a great impact on the electrical, thermal and exergy efficiencies. Moreover, these efficiencies can be enhanced by removing energy in form of heat from the surface of the photovoltaic module.
\end{abstract}

Key words: Exergy, Energy, Photovoltaic module, Performance analysis.

\section{Notation:}

\begin{tabular}{|c|c|c|}
\hline$T_{c}$ & Cell temperature & $K$ \\
\hline \hline sun & Sun temperature & ${ }^{\circ} \mathrm{C}$ \\
\hline$T a$ & Ambient temperature & ${ }^{\circ} \mathrm{C}$ \\
\hline$H a c$ & Coefficient of heat transfer by convection & $W / m^{2} \mathrm{~K}$ \\
\hline$Q$ & Convection heat transfer & $W$ \\
\hline$V$ & Wind speed & $\mathrm{m} / \mathrm{s}$ \\
\hline$G$ & Solar irradiance & $W / \mathrm{m}^{2}$ \\
\hline$\varepsilon$ & Exergy efficiency & $\square \square \square \square$ \\
\hline$\eta_{p c}$ & Power conversion efficiency & $\square \square \square \square$ \\
\hline$\eta_{\text {energy }}$ & Energy efficiency & $\square \square \square \square$ \\
\hline$E x$ solar & Solar radiation exergy & $W$ \\
\hline$E x$ elec & Electrical exergy & $W$ \\
\hline$E x$ therm & Thermal exergy & $W$ \\
\hline$P_{\text {max }}$ & Power at maximum-power point & $W$ \\
\hline
\end{tabular}

Journal of University of Babylon for Engineering Sciences by University of Babylon is licensed under a Creative Commons Attribution 4.0 International License. 
Journal of University of Babylon for Engineering Sciences, Vol. (27), No. (1): 2019.

\section{Introduction}

Nowadays, from nonrenewable energy such as fossil fuels the majority of the world's energy is generated. Because of the massive exploitation of fossil fuels, the resources of this fuel are leaded to the exhaustion and this is not the only complication, the real problem is that the exploitation of fossil fuels causes global warming, acidification of the water as well as a general threat to the environment. Fossil fuels are not equally distributed around the world since more than half reserves of oil are possed in Middle East. Fortunately, the renewable energy is an alternative for the problems listed below. The photovoltaic effect was first discovered by the physicist Edmund Becquerel in 1839. Despite that, this technology is considered to be a very recent one. The first cell which could be considered as PV was constructed in 1941 with an efficiency of $1 \%$. Since 1941, the current PV technology has been developed and as a result, they are being used not only in satellites and in space missions as a source of electrical energy but also in houses. A relative new type of photovoltaic panel is the hybrid PV which converts all the energy taken from the sun, i.e. radiation, to produce electrical energy and simultaneously, produce heat for other intentions [1]. The energy provided by the sun represents the primary source of earth's energy as well as for the progress of the human beings. The conversion of the energy provided by the sunlight into heat or electricity is not the only essential application of that energy, but also the conversion of the sunlight energy is hundreds of time useful because many applications need to reach minimum consumption pattern by storing a great quantity of solar energy [2]. Sahin et al [3] developed the exergy and thermodynamic analysis of a photovoltaic cell by using supposed properties for the chemical workings in the PV cell. The thermal energy also plays a big impact in human life since it can be applied in low temperature or high temperature. Potential solutions to wrestle greenhouse gas emission is to use solar PV and thermal modules. Jones and Underwood [4] analyzed the temperature of a photovoltaic module under the state of non-steady and with admiration to time. They reached experimental results which differed between $300-325 \mathrm{~K}$ for environmental temperature of $297.5 \mathrm{~K}$. The thermal energy that is an essential part connected to the PV module must be carried away by water or air. Also, when the PV module has attached a thermal energy, it is called hybrid $\mathrm{PV} / \mathrm{T}$ system.

Zakharchenko et al [5] analyzed a hybrid and unglazed photovoltaic thermal system with a thermal contact between the collector and the photovoltaic panel. In order to operate the photovoltaic module a low temperature, the photovoltaic panel has to cover the part of low temperature of the collector, i.e. at the inlet of the cold water. Moreover, Tripanagnostopoulos et al [6] constructed an unglazed photovoltaic thermal system. This PV/T system was constructed with booster diffuse reflector. They showed that a photovoltaic thermal system that contains reflectors provides a higher thermal energy as well as output electrical energy. They also proposed a performance for PV/air systems and PV/water. A glazed PV/T air system for single air heaters and double pass for drying and heating spaces determinations was developed by Sopian et al. [7], which investigated and produced an advanced thermal model for the previously mentioned systems. They concluded that, in glazed photovoltaic thermal systems, the thermal energy is enhanced with lower electrical efficiency as a result of high working temperatures. Also, the behavior of a concentrating photovoltaic thermal solar module was studied by Coventry [8] and demonstrated that the electrical and the overall thermal efficiencies of the $\mathrm{PV} / \mathrm{T}$ solar collector concentrating are 58 and $11 \%$ respectively, providing a total system efficiency of 69\%. Joshi and Tiwari [9] determined that the instantaneous energy and the exergy efficiency of a photovoltaic thermal system, for lower environmental temperatures in Srinagar, vary between 55-65\% and between $12-15 \%$ respectively. Moreover, the characteristics of the behavior of a photovoltaic as well as a photovoltaic thermal system was investigated by determining the exergy and energy analysis in India, specifically New Delhi. The results of their advanced approach calculated in PV cells demonstrated that it provides realistic quantities of thermodynamic properties such as entropy and enthalpy. Also, they showed that the efficiencies of PV/T modules vary in a small range, between 33 and $45 \%$ for the energy efficiency, while for the exergy efficiency between 11 and $16 \%$. Moreover, the exergy efficiency was varied from 8-14\% for a PV and they dealed with the determination of the thermal performance of a FRS-50W module by applying an energy investigation for several months of the year and taking into account the climatic condition in Iraq.

The exergy analysis is more effective and more efficient tool for the performance analysis of the solar panel. The experiment was analyzed to find the optimum temperature, which leads to the exergy efficiency analysis and to calculate the maximum efficiency and maximum solar power conversion efficiency of the module. The exergy efficiency deals with the evaluation of losses associated with the 
system from second law of thermodynamics and represents the quality of energy. However, the energy efficiency is based on the first law of thermodynamics and represents the quantity of energy rather than quality of energy and doesn't incorporate the losses/irreversibilities due to various parameters associated with the system.

\section{Experimetal setup:}

The experimental setup, shown in Fig. 1, was made-up in this work. The experimental rig with measurement devices is shown in form of a schematic diagram. There are two photovoltaic panels with and without aluminum filters used in the experimental work: solar module panel and conventional panel to compare with which were made of polycrystalline solar module (FRS-50W). The specifications of this module are given in table 1. A new connecting method is used by forming aluminum filters (Porous media) that when coupled to the absorber plate by means of rivets, the working fluid (water) will touch the absorber plate directly. Aluminum filters were used as a solar radiation absorber with an area of $(0.64 \mathrm{~m}$ $\times 0.54 \mathrm{~m}), 20 \mathrm{~mm}$ thickness. Were protected by using plates of aluminum, the panels and the aluminum filters; also, the back panel by $50 \mathrm{~mm}$ glass wool was isolated.

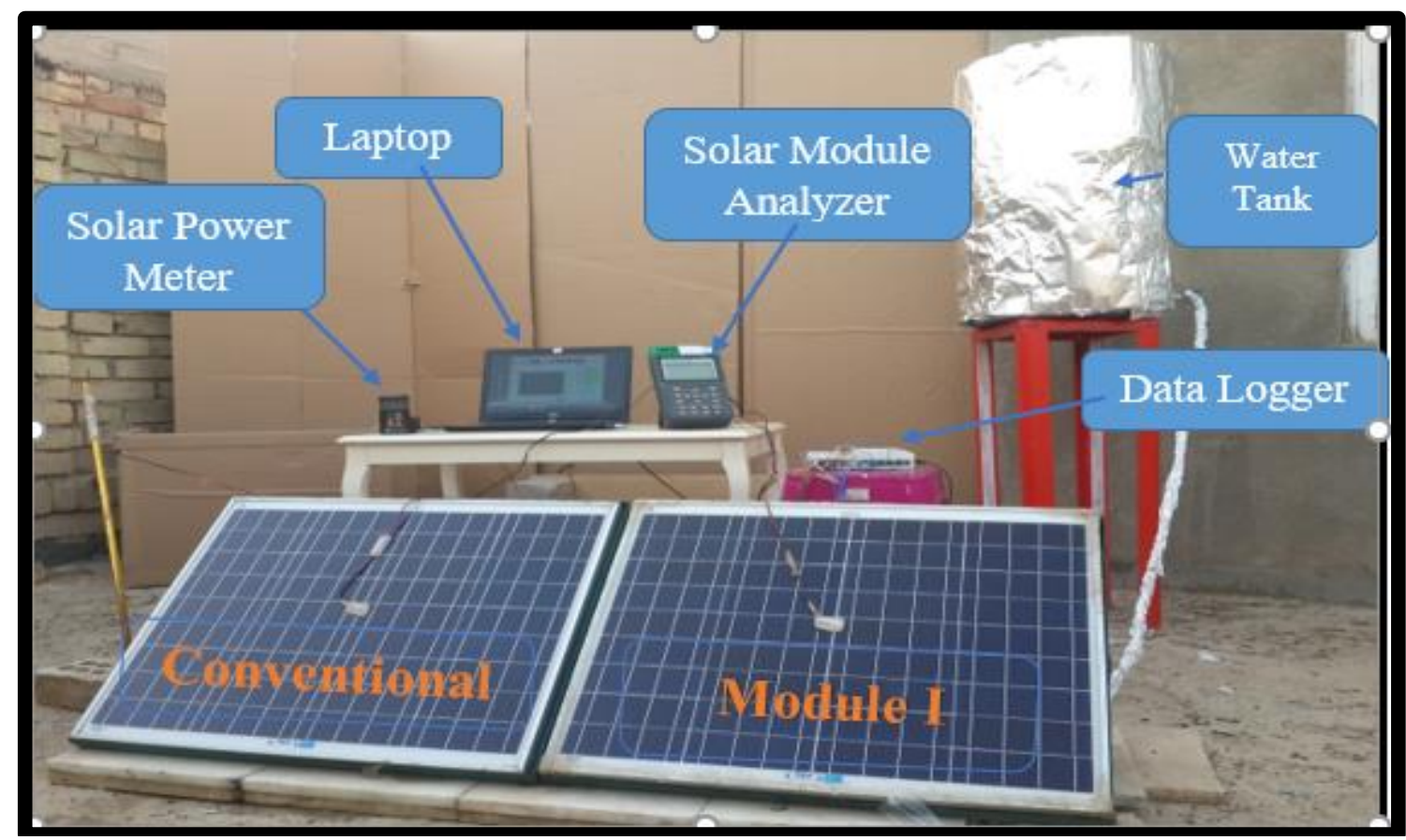

Figure (1) Experimental setup system with the measuring device.

Table (1) Electrical characteristics data of the used solar module. At STC $\left(1000 \mathrm{~W} / \mathrm{m}^{2}\right.$, cell temperature $25^{\circ} \mathrm{C}$ ).

\begin{tabular}{|l|l|}
\hline \multicolumn{2}{|c|}{ Specifications of PV Module } \\
\hline Model & $($ FRS-50W) \\
\hline Peak power(Pmax) & $50 \mathrm{~W}$ \\
\hline Voltage At Maximum Power (Vmp) & $18 \mathrm{~V}$ \\
\hline Current At Maximum Power (Imp) & $2.8 \mathrm{~A}$ \\
\hline Open Circuit Voltage(Voc) & $22 \mathrm{~V}$ \\
\hline Short Circuit Current (Isc) & $3.17 \mathrm{~A}$ \\
\hline Total Number Of Cells & $36(4 \times 9)$ \\
\hline Module dimension & $(640 \times 540 \times 25) \mathrm{mm}$ \\
\hline
\end{tabular}




\subsection{Open-cell aluminum filter}

By using porous materials like the aluminum filter, which has an $80 \%$ of porosity, the heat transfer rate is enhanced in heat exchangers, this technique is relatively new. This type of material is a potential material for uses in thermal handling, absorption of energy and for lightweight structures because it has a high surface area to volume ratio and mix fluid flow. It is covered all back surfaces of the PV to increase the contact surface area, Fig. 2.

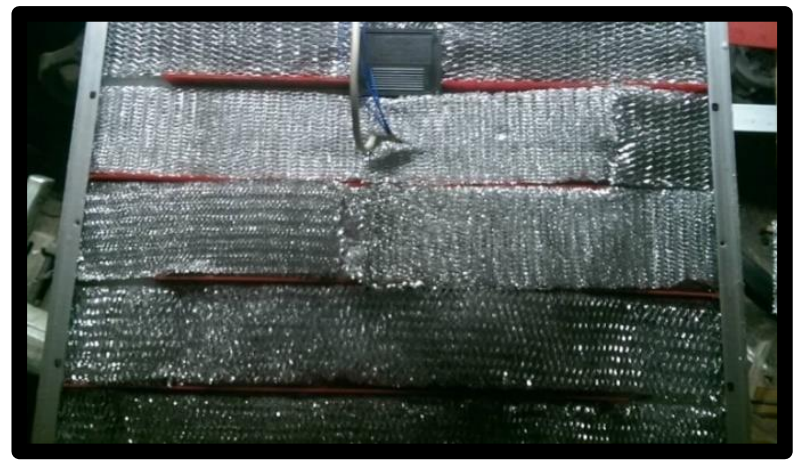

Figure (2) Aluminum filter

\subsection{Water Box (Heat Exchanger)}

The heat exchanger and the hull is a box of dimensions $(67 * 54 \mathrm{~cm})$ and configurations with thickness $(2.5 \mathrm{~cm})$ containing five passages of water that enter the water from the bottom and walk through the heat exchanger pathways where the heat acquires the back of the photovoltaic cell and exits the top. These configurations are designed depending on open cell aluminum filter thickness. Fig. 3

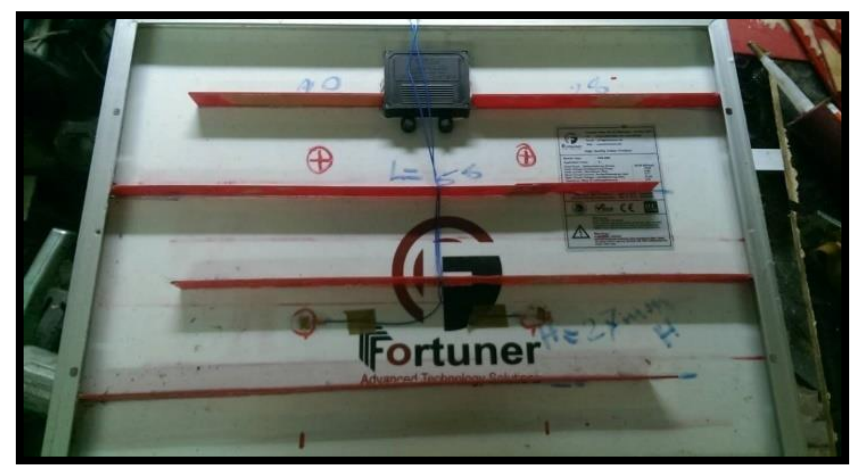

Figure (3) Heat exchanger

\section{Efficiency Analysis:}

The ability of PV solar systems to convert sunlight into electrical energy is measured and called as the efficiency of photovoltaic modules, which is a vital and important magnitude that measure and foresee the performance of PV solar modules. The ability of these modules of converting the sunlight energy into electrical energy for human consumption is represented by the efficiency of the system. The efficiency of the PV module is determined as the ratio between the total power energy generated and the solar irradiation. The exergy represents an amount of the maximum work utilizable that the PV system can remove when it undergoes a reversible process from the initial to the final state. The determination of this parameter, the exergy, helps investigators to understand in an accurate way the performance of photovoltaic solar modules. The design and evaluation of energy system can be analyzed by an exergy analysis which is a measurement of the changes in the energy of the system until it reaches an equilibrium state with the environment (Sandnes, 2003). The determination of the energy efficiency does not foresee information about the degradation of the thermal and electrical energy during the operational state but it is useful since 
it allows determining the energy flows. In order to determine this parameter, it is necessary to formulate the equation of the second law of thermodynamics in terms of efficiencies, and determine the degradation of exergy quality as well as the exergy consumption. An analysis that has been proven and has demonstrated to provide a powerful source of determination of the quality losses in thermodynamic process in the industrial area is the exergy analysis. The second law efficiencies measure a reversible and ideal process and compare it to a real process [10]. PV efficiency can be determined as the ratio between the useful exergy, i.e. thermal and electrical exergy rates, and the exergy of the rate of solar radiation [11]:

$$
\varepsilon=\frac{\text { Ex out }}{\text { Ex solar }}
$$

Where Ex solar is the exergy of solar radiaton and it is determined by applying equation (2):

$$
\text { Ex solar }=\left(1-\frac{T a}{T s u n}\right) . G \cdot A
$$

Where Tsun is the temperature of the sun, which is assumed to be $5777 \mathrm{~K}$ [11], the intensity of the solar radiation is denoted as $\mathrm{G}$ and the $\mathrm{PV}$ module area is denoted as $\mathrm{A}$.

The output of the PV module can be determined by applying equation (3):

$$
\text { Ex out }=\text { Ex elec }- \text { Ex therm (3) }
$$

The rate of electrical exergy Ex elec is equal to the generated electric power by the PV system:

$$
\text { Ex ele }=\text { Pmax }
$$

The Ex therm is the thermal exergy of the PV module and can be calculated by applying equation below [12]:

$$
\text { Ex therm }=\left(1-\frac{T a}{T c}\right) \cdot Q
$$

The amount of the heat transfer rate by means of convection can be determined by applying the following equation:

$$
Q=H a c \cdot A .(T c-T a)(6)
$$

Where Hac is the convective heat transfer coefficient, and the expression shown below allows determine it [13]:

$$
H a c=2.8+3 * v(7)
$$

The wind $\operatorname{speed}(v)$ was not measured. Values were taken from the [14].

The efficiency of power conversion of the PV module is defined as a ratio between the output electrical energy and the incident solar radiation on the photovoltaic surface area [15]:

$$
\eta_{p c}=\frac{p_{m p}}{G \cdot A}
$$

The following equation allows determining the energy efficiency of PV solar modules:

$$
\boldsymbol{\eta}=\frac{\boldsymbol{\eta}_{p c}}{\boldsymbol{F} \cdot \boldsymbol{F}}
$$

The relation between the maximum magnitude of the generated power and the product of the circuit voltage in the open case and the short circuit current is called the fill factor (F.F). 


\section{Results and Discussion}

The experiment was carried out in order to determine the optimum temperature from the analysis of exergy efficiency. Also, was calculated the maximum efficiencies of the system and power conversion of the module. The exergy determination involves an analysis of the losses by applying the second law of thermodynamics as a way to measure the quality of the energy, but the first law of the thermodynamics is the one that represents the quantity of energy and its efficiency without taking into account the irreversibilities of the system.

The difference between the exergy, power conversion and the energy efficiencies are illustrated in Figure 4, where it can be seen that the minimum and maximum are varying as follows: (6.89-14.6)\%, (5.53-10.18) \% and (8.7-10.3) \% respectively in the $10 / 5$ as well as in the $23 / 6$ are found to be changed between $(8.16-14.95) \%,(6-11.2) \%$ and $(5.8-12) \%$ respectively. On $26 / 6$ it is also found that the fluctuation in all the three efficiencies are (7.43-14.28) \%, (5.65-10.9) \% and (2.15-12.27) \% respectively as well as in the $3 / 7$ also found that the fluctuation in all the three efficiencies are (7.07-13.37) \%, (5.21$9.75) \%$ and $(5-12.5) \%$ respectively.

According to these results, was concluded that the exergy efficiency of photovoltaic solar module is diminished while the thermal radiation from the sun increases as well as the environmental temperature because of the cell's irreversibility, which also produces an increase in the electrical generation.

The efficiency of the energy always presents magnitudes with higher values that the efficiencies of the exergy and the power consumption; however, in the mornings and afternoons of May, June and July, the efficiency of the exergy presented higher values than the energy and power conversion.

Figure 5 indicated the changes in solar exergy, which is the input exergy, and the electrical exergy of the photovoltaic solar module through different days. In these Figures it can be appreciated that the electrical exergy is significantly inferior that the energy that could be extracted, indicating that there were highly losses due to the system's irreversibility.

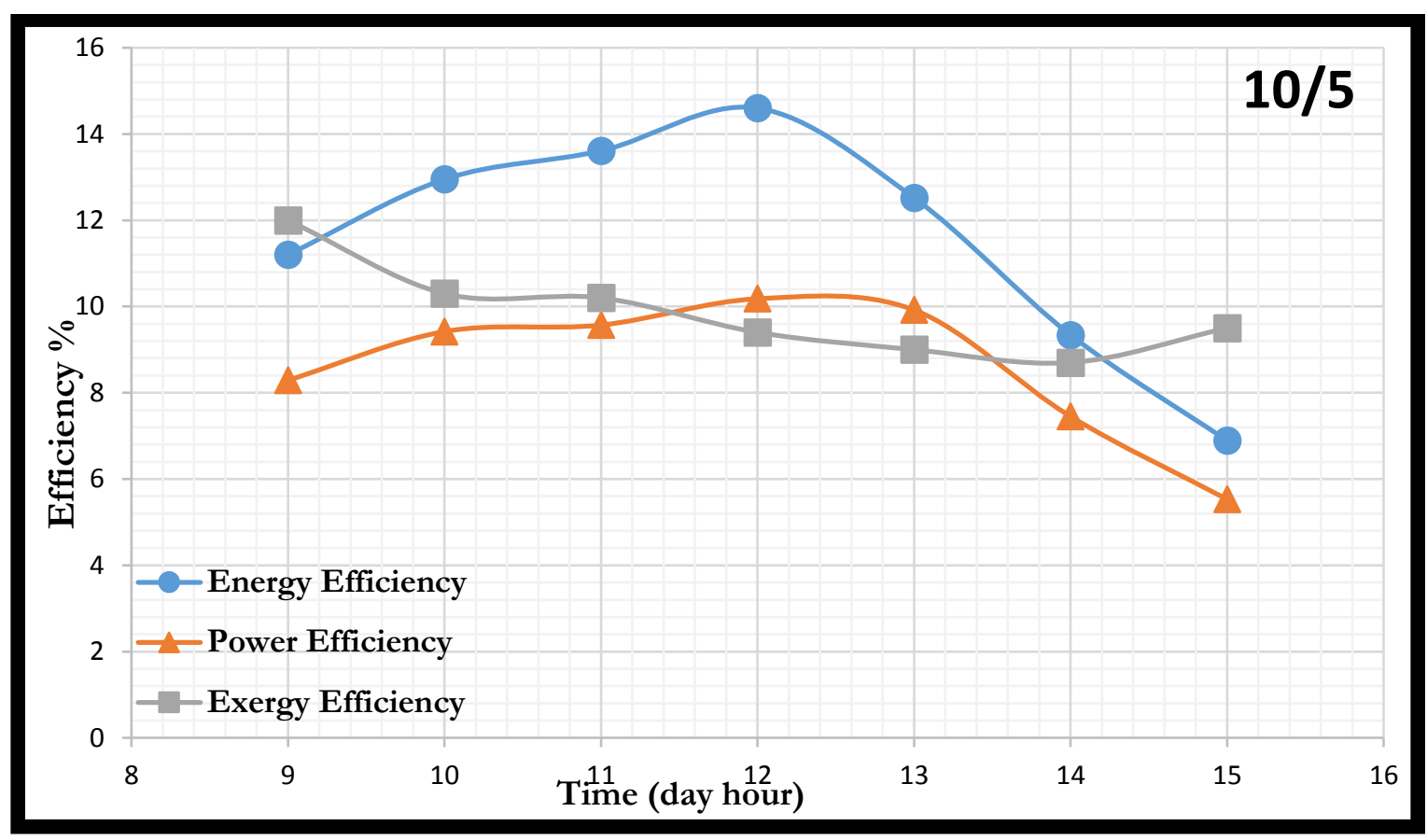

Figure (4) Changes of energy, exergy and power conversions efficiency with time. 

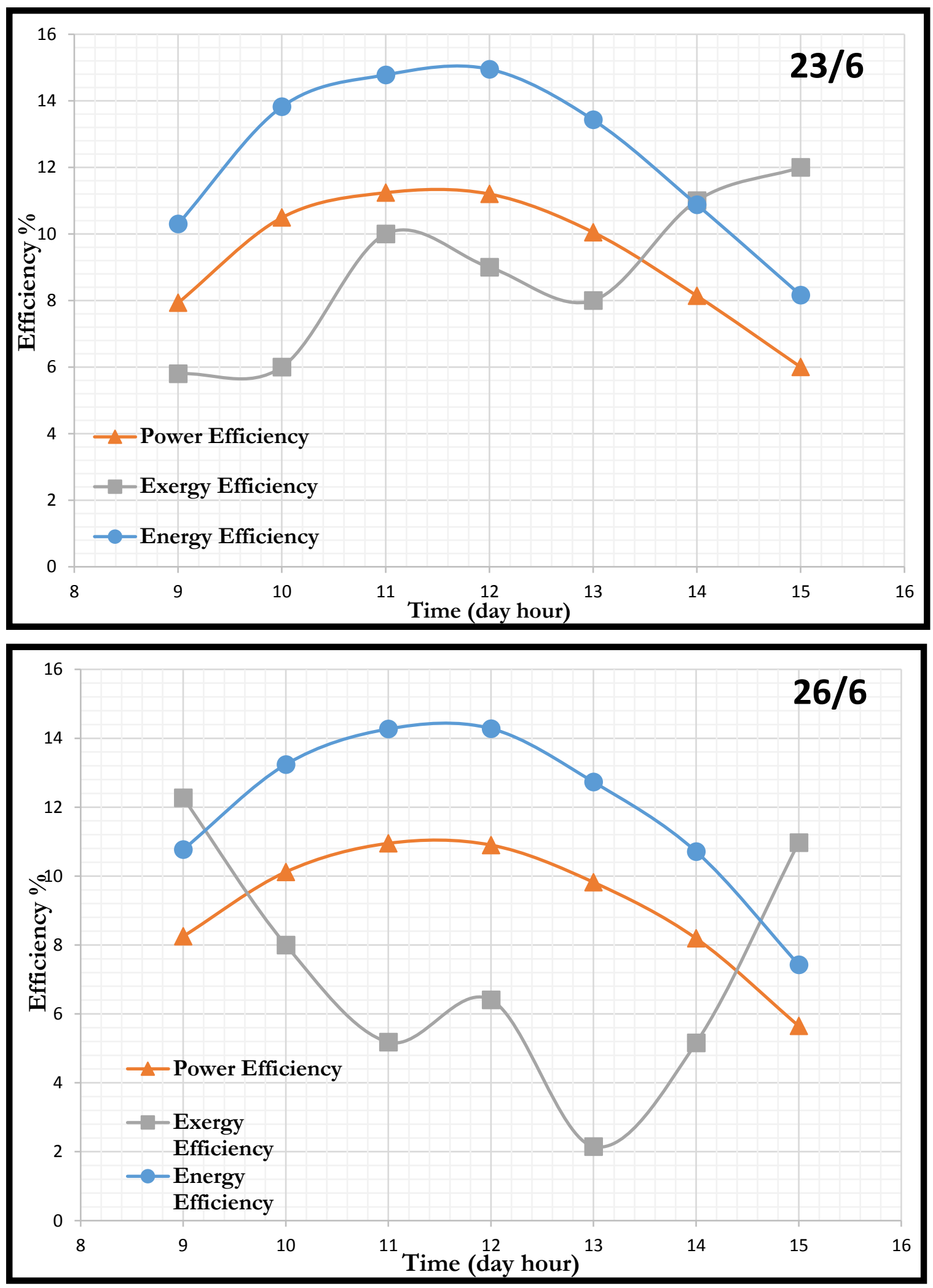

Figure (4) Changes of energy, exergy and power conversions efficiency with time. 


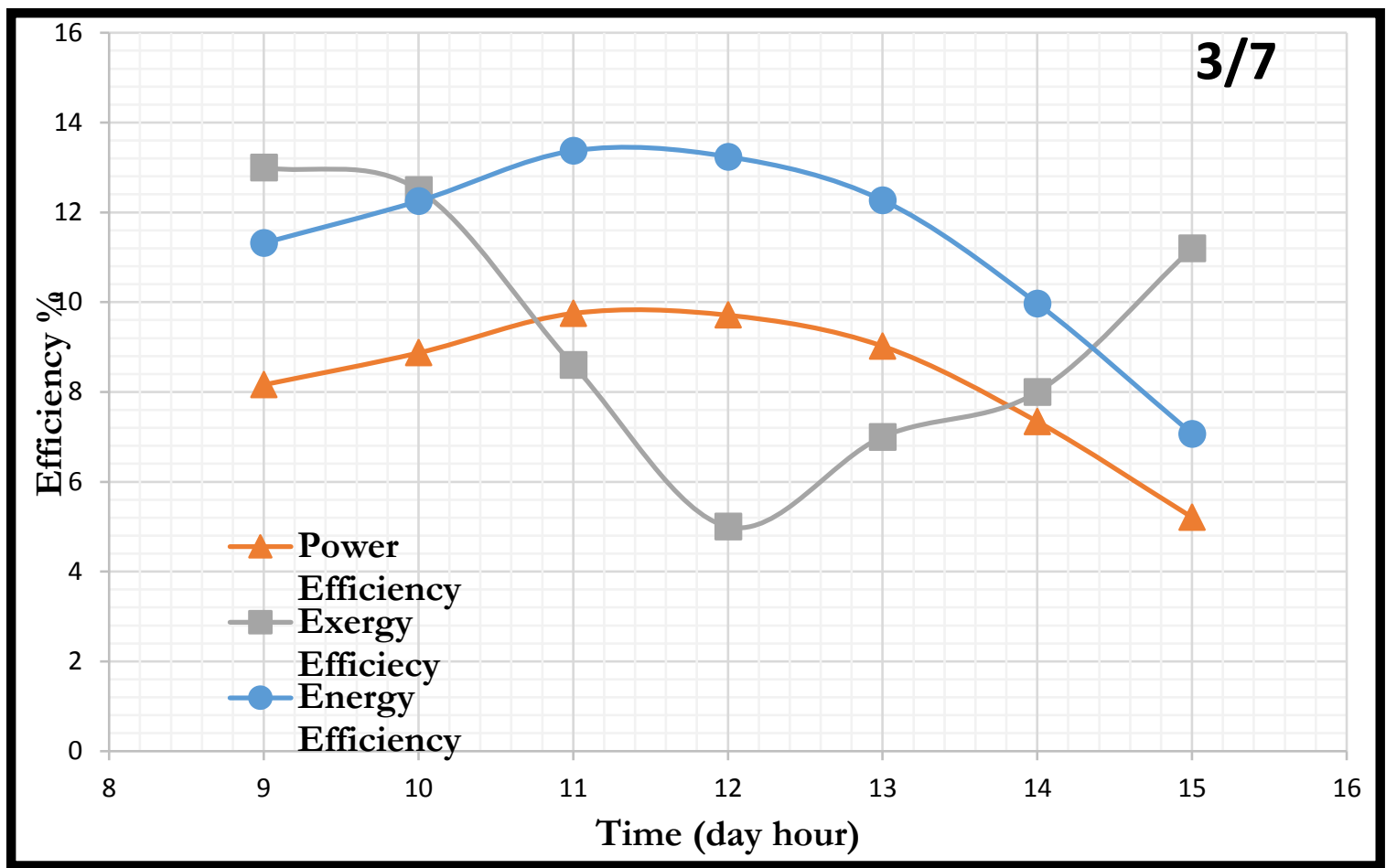

Figure (4) Changes of energy, exergy and power conversions efficiency with time.

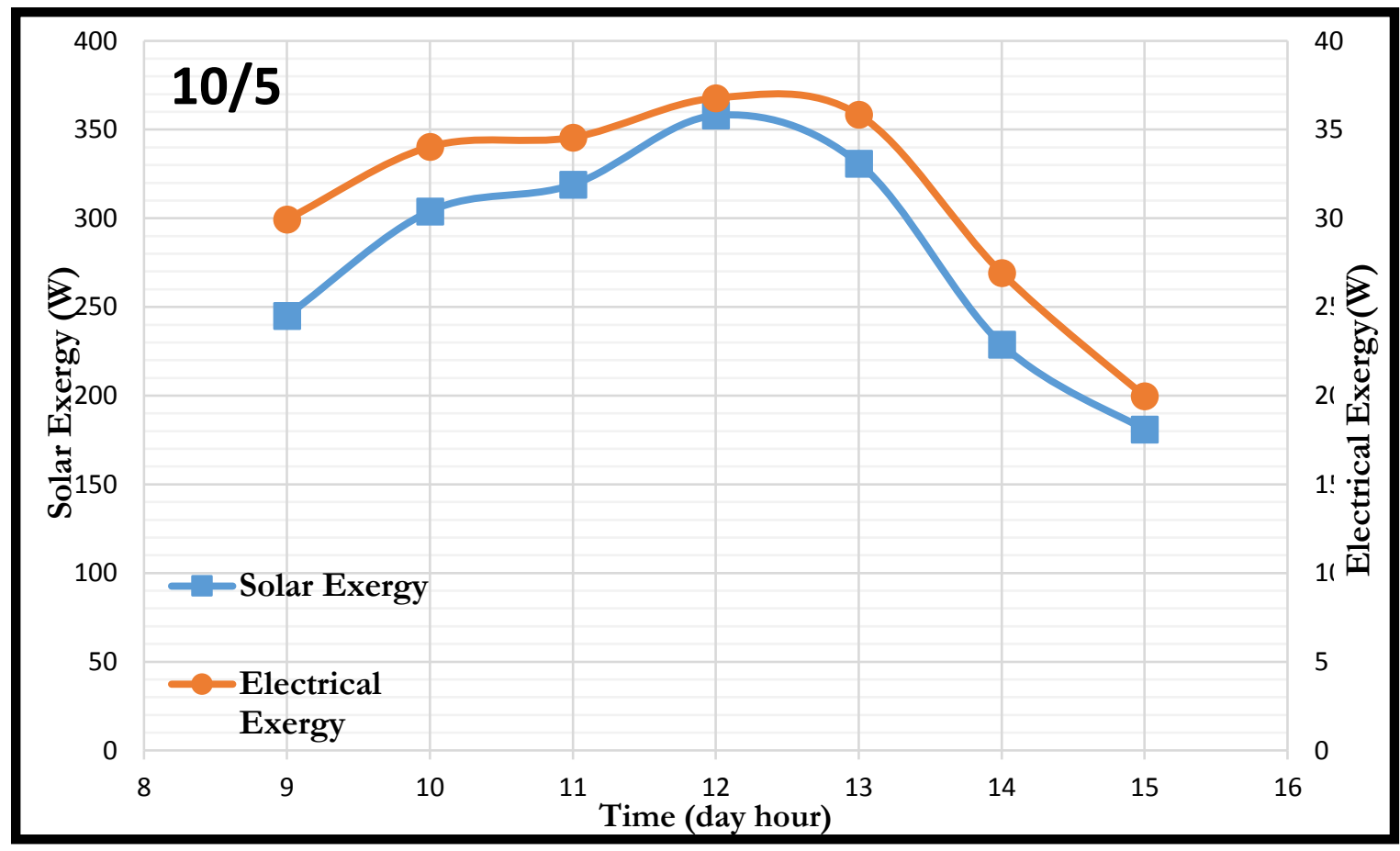

Figure (5) Changes of solar exergy and electrical exergy with time. 
Journal of University of Babylon for Engineering Sciences, Vol. (27), No. (1): 2019.
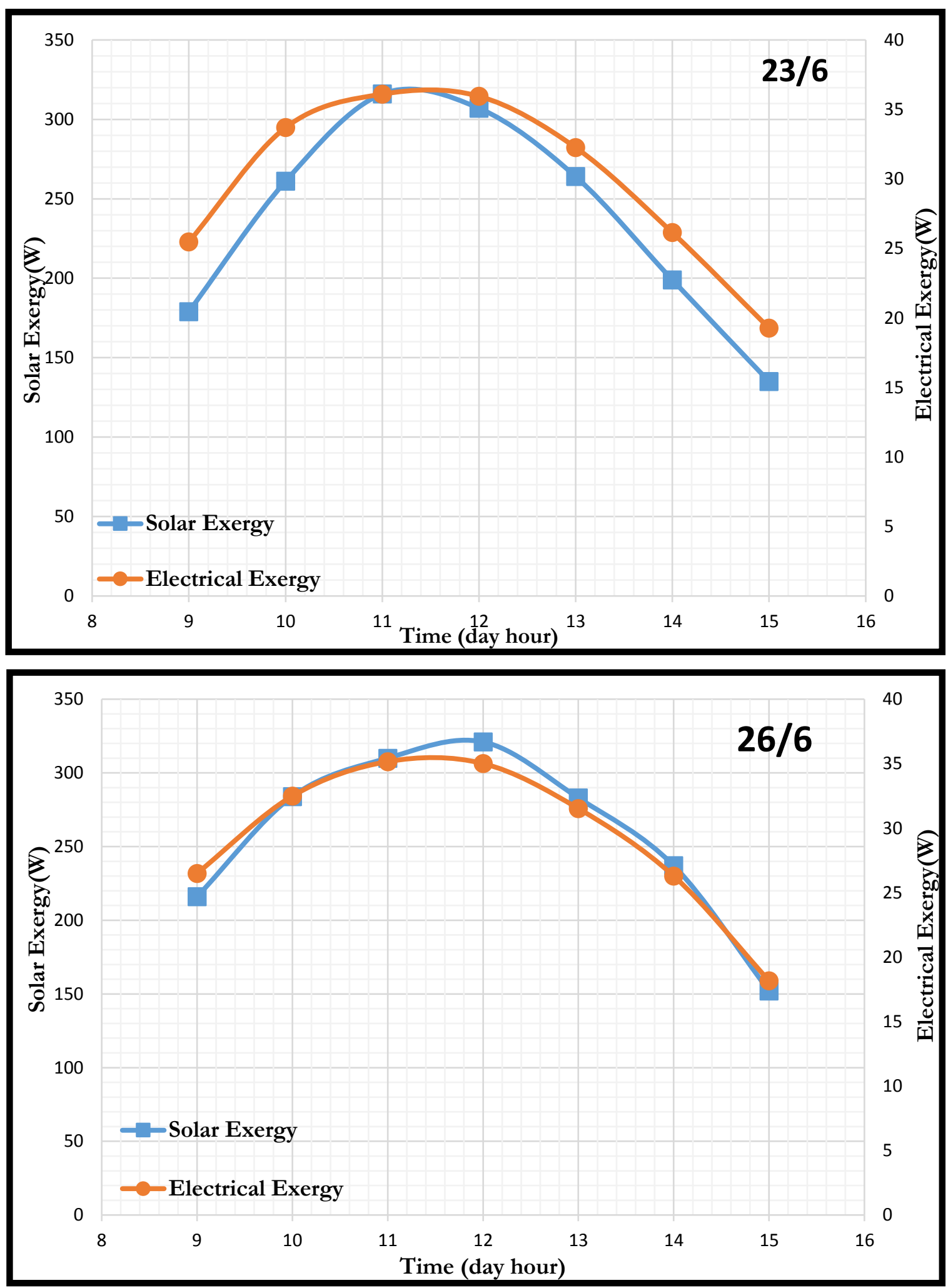

Figure (5) Changes of solar exergy and electrical exergy with time. 


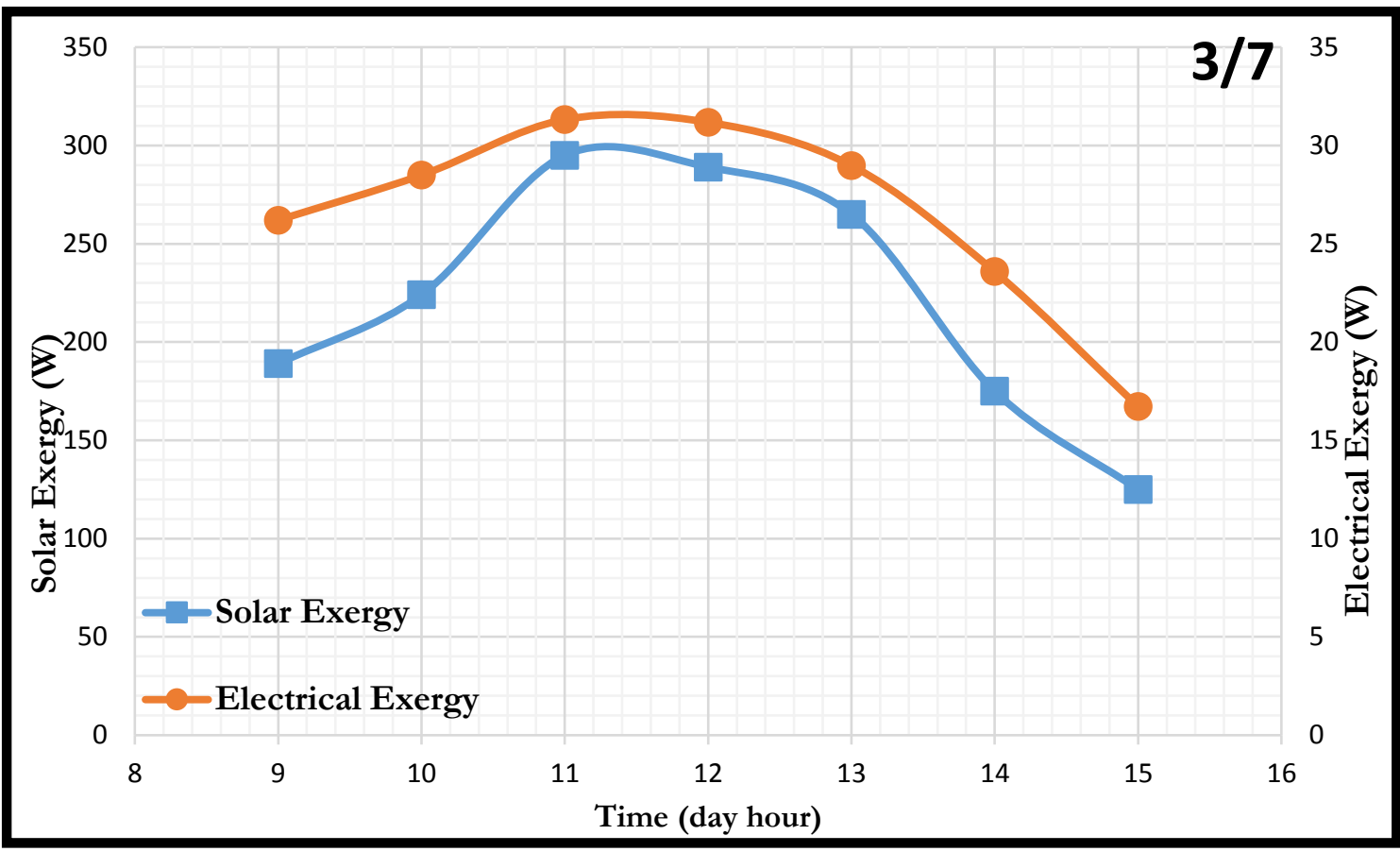

Figure (5) Changes of solar exergy and electrical exergy with time.

\section{Conclusions}

This research project presents the experimental analysis of the performance of a $50 \mathrm{~W}$ polycrystalline photovoltaic solar module with bases on the analysis of the exergy and energy in the region of Baghdad. The experimental data were gathered during the complete month of June (2018) and analyzed in order to evaluate the maximum efficiencies of the module. The losses in the PV process of conversion for the thermal exergy were calculated and the following conclusions were reached:

1-The polycrystalline photovoltaic solar module is highly dependent on the rate of thermal energy provided by the sun. When radiation of the sun is low that mean the efficiency is also low of the module when radiation is high-the efficiency is also maximum to do by the PV module.

2- When ambient temperature and solar radiation rises in summer days due to increasing the cell temperature and irreversibility (energy losses) of the module. That condition the output power (Electricity) rises.

3- Exergy analysis is one of the most effective and efficient tools for analyzing of the solar panel behavior. The value of energy, power conversion and exergy efficiencies (module I) are found to be (14.6\%, $10.18 \%$ and $9.4 \%$ ) respectively in the $10 / 5$ at $12: 00$ as well as in the $23 / 6$ and $26 / 6$ at 12:00 are found to be $(14.9 \%, 11.2 \%, 9 \%)$ and $(14.28 \%, 10.9 \%, 6.41 \%)$ respectively. On $3 / 7$ at $12: 00$ it is also found that the fluctuation in all the three efficiencies is $(13.24 \%, 9.71 \%, 5 \%)$ respectively. Thesis done for the improvement of efficiency of solar module can prove to be highly beneficial. It can be made cost effective by developing low cost semiconductor materials and thus the cost of electricity generation can be reduced.

4-Study done for the enhancement of efficiency of PV solar module can verify to be highly useful. It can be completed cost effectively by developing low cost semiconductor materials and thus cost of power generation can be reduced.

\section{CONFLICT OF INTERESTS.}

- There are no conflicts of interest. 


\section{References}

[1] Ajam H, Farahat S, Sarhaddi F. Exergetic optimization of solar air heaters and comparison with energy analysis. International Journal of Thermodynamics 8(4):183-190, 2005.

[2] Akyuz E, Coskun C, Oktay Z, Dincer I. A novel approach for estimation of photovoltaic exergy efficiency. Energy. 44(1):1059-1066, 2012.

[3] Ankit Singh, O.P Shukla and Nishant saxena, "Energy and Exergy Analysis of Crystalline Silicon Solar Photovoltaic Module for clear sky Day at Bhopal", International Research Journal of Engineering and Technology (IRJET), 2016.

[4] Coventry SJ., Performance of a concentrating photovoltaic/thermal solar collector. Solar Energy; 78:211-22, 2005.

[5] EfstratiosChaniotakis, "Modelling and Analysis of Water Cooled Photovoltaics ", M.Sc. thesis, University of Strathclyde, 2001.

[6] F. Grubišić-Čabo, S. Nižetić and T. Giuseppe Marco, "Photovoltaic Panels: A Review of the Cooling Techniques", transactions of famena $\mathrm{xl}$ - special issue 1, University of Catania, Italy, 2016.

[8] J. K. Tonui and Y. Tripanagnostopoulos, "Improved PV/T solar collectors with heat extraction by forced or natural air circulation", Renewable Energy 32, pp. 623-637, 2007.

[9] Jones AD, Underwood CP., A thermal model for photovoltaic systems. Solar Energy ;70:349-59, 2001.

[10] Joshi AS, Tiwari A., Energy and exergy efficiencies of a hybrid photovoltaic thermal (PV/T) air collector. Renew Energy; 32:2223-41, 2007.

[11] Joshi, A.S., Dincer, I., Reddy, B.V., Thermodynamic assessment of photovoltaic systems, Solar Energy, 83, pp. 1139-1149, 2009.

[12] Pandey A, Pant P, Sastry O, Kumar A, Tyagi S, Energy and exergy performance evaluation of a typical solar photovoltaic module. Thermal Science 19(2):625-636, 2015.

[13] Sahin AD, Dincer I, Rosen MA. Thermodynamic analysis of solar photovoltaic cell systems. Solar Energy Mater Solar Cells 2007; 91:153.

[14] Sopian K, Liu HT, Kakac S, Performance of a double pass photovoltaic thermal solar collector suitable for solar drying systems. Energy Convers Manage; 41:353-65, 2000.

[15] Sulaf Adnan Al-Noori and Abeer Yihya Al-Sakini, "The Possibility of Employing the Winds in Iraq in Producing the Electric Energy”. College of Basic Education / University of Al-Mustansiriya, 2014.

[16] Tripanagnostopoulos Y, Nousia TH, Souliotis M, Hybrid Photovoltaic/Thermal solar system. Solar Energy; 72:217-34, 2002. 
Journal of University of Babylon for Engineering Sciences, Vol. (27), No. (1): 2019.

\section{الطاقة وحساب الاداء الخارجي للطاقة الثمسية لنظام كهروضوئي /حراري في مدينة بغداد

zaid.sal87@gmail.com Mohammed2007msc@yahoo.com $\underline{\text { dr.dheya@gmail.com }}$

الخلاصة

نظام الطاقة الثمسية الكهروضوئية / الحرارية (PV / T) هو نظام مدمج ينكون من وحدات PV مع وسائط استخر اج الحرارة

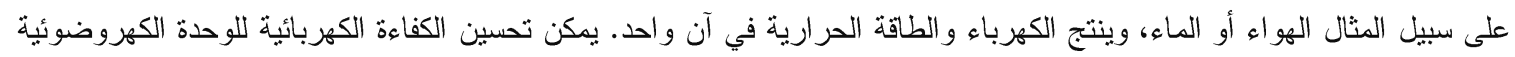
عن طريق خفض درجة حرارة التثغيل لوحدة الطاقة الكهروضوئية عن طريق إز الة الطاقة الحرارية في وقت واحد و التي ترتبط

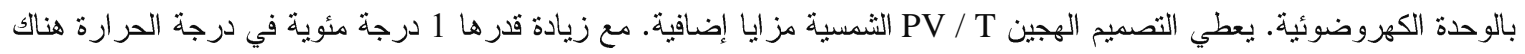

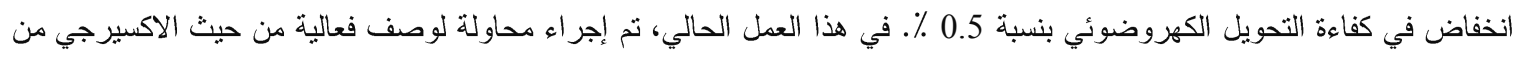

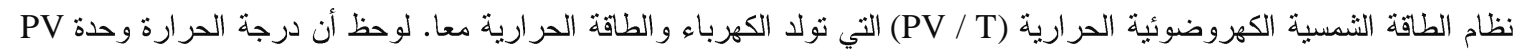

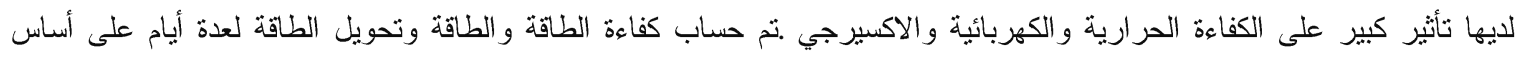

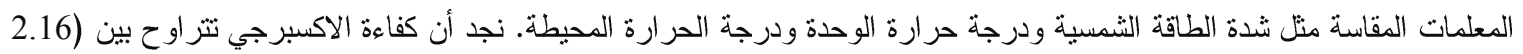

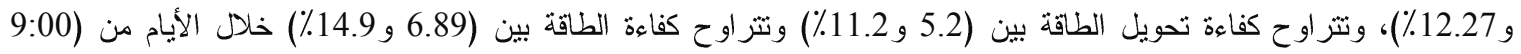

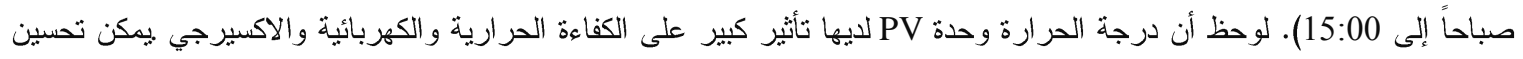
الكفاءة الحر ارية و الكهربائية والعفوية إذا أمكن إز الة الحرة الحرة ارة من سطح الوحدة الكهروضوئية. كلمات الاداله: الاكسيرجي، الطاقة، وحدة كهروضوئية، تحليل الاداء. 